\title{
Minority Group
}

National Cancer Institute

\section{Source}

National Cancer Institute. Minority Group. NCI Thesaurus. Code C16863.

A minority is a group that is outnumbered by persons who do not belong to it, often people with different nationality, religion, culture or lifestyle from that of the mainstream in the society; racial or ethnic groups officially recognized by the U.S. government as minority populations. 